OPEN ACCESS

Edited by: Amir Garakani, Yale Medicine, United States

Reviewed by: Marian L. Logrip, Indiana University,

Purdue University Indianapolis, United States

Kabirullah Lutfy, Western University of Health Sciences,

United States

*Correspondence:

Charles B. Nemeroff cnemeroff@austin.utexas.edu

Specialty section: This article was submitted to Psychopharmacology, a section of the journal Frontiers in Psychiatry

Received: 24 January 2020 Accepted: 01 May 2020 Published: 15 May 2020

Citation:

Tafet GE and Nemeroff CB (2020) Pharmacological Treatment of Anxiety Disorders: The Role of the HPA Axis. Front. Psychiatry 11:443. doi: 10.3389/fpsyt.2020.00443

\section{Pharmacological Treatment of Anxiety Disorders: The Role of the HPA Axis}

\author{
Gustavo E. Tafet ${ }^{1}$ and Charles B. Nemeroff ${ }^{2 *}$ \\ ${ }^{1}$ Department of Psychiatry and Neurosciences, Maimónides University, Buenos Aires, Argentina, ${ }^{2}$ Department of Psychiatry, \\ University of Texas at Austin, Austin, TX, United States
}

Stress in general, and early life stress in particular, has been associated with the development of anxiety and mood disorders. The molecular, biological and psychological links between stress exposure and the pathogenesis of anxiety and mood disorders have been extensively studied, resulting in the search of novel psychopharmacological strategies aimed at targets of the hypothalamic-pituitaryadrenal (HPA) axis. Hyperactivity of the HPA axis has been observed in certain subgroups of patients with anxiety and mood disorders. In addition, the effects of different anti-anxiety agents on various components of the HPA axis has been investigated, including benzodiazepines, tricyclic antidepressants (TCAs), and selective serotonin reuptake inhibitors (SSRIS). For example, benzodiazepines, including clonazepam and alprazolam, have been demonstrated to reduce the activity of corticotrophin releasing factor (CRF) neurons in the hypothalamus. TCAs and SSRIs are also effective anti-anxiety agents and these may act, in part, by modulating the HPA axis. In this regard, the SSRI escitalopram inhibits CRF release in the central nucleus of the amygdala, while increasing glucocorticoid receptor (GRs) density in the hippocampus and hypothalamus. The molecular effects of these anti-anxiety agents in the regulation of the HPA axis, taken together with their clinical efficacy, may provide further understanding about the role of the HPA axis in the pathophysiology of mood and anxiety disorders, paving the way for the development of novel therapeutic strategies.

Keywords: pharmacology, anxiety, hypothalamic-pituitary-adrenal, corticotropin releasing hormone, stress

\section{INTRODUCTION}

Stress, and more specifically, early life stress, has been associated with the origin and development of depression and anxiety disorders (1-6). In this regard, it has been shown that chronic exposure to environmental stressors is followed by a set of adaptive responses, mediated by the activation of different neural structures involved in emotional and cognitive processing in the central nervous system (CNS), and the subsequent activation of the autonomic nervous system (ANS) and the hypothalamic-pituitary-adrenal axis (HPA) $(7,8)$. Environmental stressors are perceived and transmitted through sensory pathways to different structures in the CNS, including the thalamus and limbic areas, such as the amygdala and the hippocampus, and cortical areas, mostly located 
in the prefrontal cortex (PFC). Direct projections from the thalamus to the amygdala may provide primitive representations of stimuli, which in turn are potentiated by noradrenergic stimulation from the locus coeruleus (LC) to initiate a primary stress response. Indirect projections may also reach the amygdala from sensory and associative cortices, and transitional cortices, associated to the hippocampus (9). Hence, the hippocampus projects forward to the lateral nucleus of the amygdala, as well as the hypothalamic paraventricular nucleus (PVN), where it plays an inhibitory role $(10,11)$. The lateral nucleus of the amygdala projects to the basal, accessory basal, and central nuclei of the amygdala (CeA) (12). Therefore, the CeA projects to the lateral nucleus of the hypothalamus, which activates the sympathetic branch of the ANS (13), the dorsal motor nucleus of the vagus, which activates the para-sympathetic branch, and the PVN, therefore leading to the activation of the HPA axis $(13,14)$. Hence, the HPA axis may be activated through direct projections from the $\mathrm{CeA}$, which project to the PVN (7), where the corticotropin releasing hormone (CRH, also termed corticotrophinreleasing factor, CRF) is synthesized and released into the hypophyseal portal blood to reach the anterior pituitary. CRH stimulates the transcription of the pro-opiomelanocortin (POMC) gene, a common precursor for adrenocorticotropic hormone (ACTH) and related peptides. ACTH is released into the bloodstream to reach the adrenal cortex, where it stimulates the biosynthesis and release of glucocorticoids, mainly cortisol (illustrated in Figure 1). These steroid hormones exert their effects through binding to mineralocorticoid receptors (MRs or type I) and glucocorticoid receptors (GRs or type II), constituting a hormone-receptor complex, which in turn may interact with specific DNA sequences located in the promoter region of target genes, termed glucocorticoid response element (GRE) (15), stimulating or inhibiting the expression of target genes. This has been described for the down-regulation of the POMC (16) and CRH genes (17), whereby cortisol is able to regulate its own synthesis and release through the negative feedback mechanisms that regulate HPA axis activity. In addition, cortisol may also down-regulate the HPA axis by binding to hippocampal GRs, which in turn inhibit the PVN, as well as exerting tonic inhibition through binding to hippocampal MRs $(18,19)$. During chronic stress these negative-feedback loops may be abolished, resulting in persistent activation of the HPA axis (15). Therefore, physiological rhythms characterized by wide diurnal variations, with morning zeniths and evening nadirs, are altered during chronic stress, which in turn may be translated into sustained increase in cortisol levels (1). In addition, chronic stress may also lead to decreased expression of brain derived neurotrophic factor (BDNF) in the hippocampus, which in turn may reduce its capability to inhibit the HPA axis $(20,21)$.These persistent alterations in the regulation of the HPA axis, such as the observed during chronic stress, has been associated with the origin and development of mood and anxiety disorders, where hyperactivity of the HPA axis, and the consequent hypercortisolism, represents one of the most consistent biological findings $(6,22,23)$.

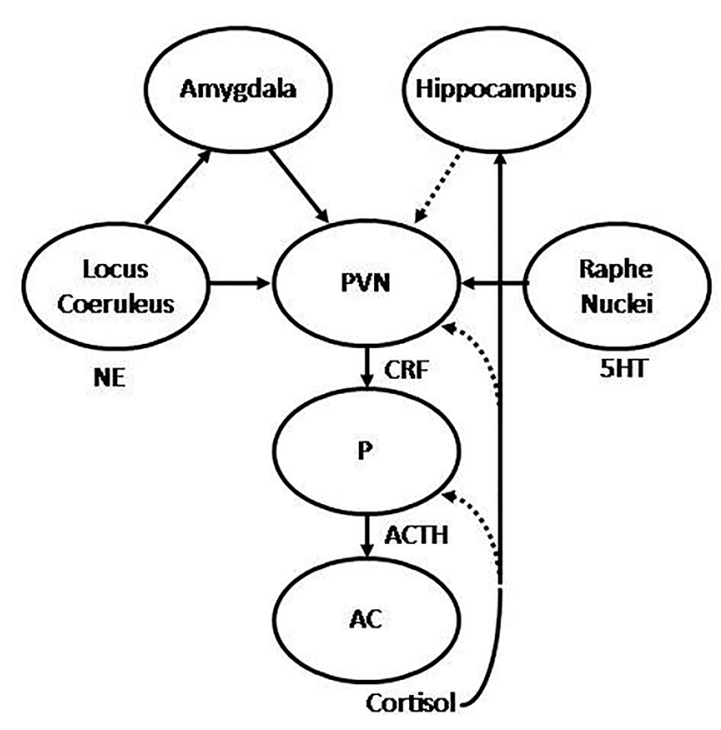

FIGURE 1 | Graphic representation of the hypothalamic-pituitary-adrenal (HPA) axis. The hypothalamic paraventricular nucleus (PVN) releases corticotropin releasing hormone $(\mathrm{CRH})$ to the hypophyseal portal blood, to reach the pituitary $(\mathrm{P})$, where adrenocorticotropic hormone $(\mathrm{ACTH})$ is synthesized and released to systemic blood to reach the adrenal cortex (AC), where in turn cortisol is synthesized and released to the main bloodstream. The HPA is regulated by stimulatory projections from the amygdala and inhibitory projections from the hippocampus. In addition, the PVN receives noradrenergic projections from the locus coeruleus (LC) and serotonergic projections from the raphe nuclei (RN). Stimulatory and inhibitory feedback loops are also represented, where cortisol is able to regulate its own synthesis and release by inhibiting $\mathrm{ACTH}$ and $\mathrm{CRH}$ synthesis in the pituitary and PVN respectively, and stimulating the hippocampus, which in turn may inhibit the PVN. Under repeated uncontrollable stress these feedback mechanisms result abolished, with the consequent hypercortisolism, alongside with increased reactivity of the amygdala and decreased activity of the hippocampus. Successful treatment is translated into recovery of these feedback mechanisms, with the consequent normalization of cortisol, decreased amygdala reactivity, increased hippocampal function, and normalization of noradrenergic and serotonergic systems.

\section{THE ROLE OF THE HPA AXIS}

Hyperactivity of the HPA axis is associated with increased synthesis and release of CRH from hypothalamic neurons in the PVN in response to stress. CRH-containing neurons have been also observed in other neural structures, such as the CeA $(24,25)$, which in turn activates the HPA axis through stimulatory projections to the PVN. In addition, reciprocal connections have been also observed between these CRH neurons and aminergic nuclei, including the LC and the raphe nuclei (RN) (4), therefore providing additional pathways for reciprocal interaction between the noradrenergic and the serotonergic systems, respectively, with the HPA axis during the stress response $(4,26)$ (illustrated in Figure 1). Thus, CRH neuronal circuits interact with the serotonergic and the noradrenergic systems, which are critically involved in mood and anxiety disorders (3). Moreover, CRH has been also 
associated with anxiety and encoding of emotional memories (3, 22) thus highlighting the critical role of the CRH system in the stress response and its role as an important factor in the longlasting effects of stress, particularly regarding early life stressful experiences. In this regard, it has been shown that the impact of traumatic events during childhood represents a critical factor of vulnerability in the origin and development of mood and anxiety disorders later in life $(4,27,28)$. The link between early adverse experiences, such as abuse, neglect or loss, and the development of mood and anxiety disorders has been shown to occur as a consequence of stressful conditions during different periods of life (29). Various studies focused on alterations in different limbic structures and the HPA axis. In this regard, it has been shown that exposure to early stressful events may lead to decreased availability and reduced efficacy of hippocampal GRs (27), which in turn may lead to glucocorticoid resistance and increased reactivity of the HPA axis in response to stressful situations later in life. Moreover, it has been shown that increased concentrations of cortisol along with decreased GRs induced by early stressful events were associated with decreased hippocampal function and volume in adulthood (30). Therefore, the impact of early adverse events may lead to long lasting changes, including hyper-reactivity of neural and neuroendocrine responses to stress, reflected in increased $\mathrm{CRH}$, glucocorticoid resistance and reduced volume of the hippocampus $(27,31)$, all of which may contribute to shape potential responses to further stressful experiences later in life.

\section{THE ROLE OF THE SEROTONERGIC SYSTEM}

It has been shown that deficient or altered serotonergic neurotransmission in the CNS plays a critical role in the origin and development of anxiety and depressive symptoms (26). The serotonergic system has its main sources in the RN, which project to diverse neural structures (illustrated in Figure 2). Serotonergic projections to the forebrain originate mainly in the dorsal (DRN) and medial RN (MRN) (32). The DRN-forebrain tract innervates various structures, many of them associated with anxiety-related and adaptive responses to stress (33-35), including the CeA (36), the bed nucleus of the stria terminalis (BNST) (37), the PVN, the nucleus accumbens (NAc), and certain areas of the PFC, particularly the medial PFC (MPFC) (38). In addition, the DRN also innervates structures related to regulation of fight-or-flight behavioral responses, such as the periaqueductal grey $(\mathrm{PAG})(39,40)$ and the striatum, which have been shown to be involved in passive coping behavior (41). Both neural structures, the PAG and the striatum, have also been associated with the state of anticipatory anxiety that plays a critical adaptive role in situations of danger, contributing to inform the amygdala about the current impact of negative experiences and the consequent emotional reactions (11). The MRN-forebrain tract projects to complementary neural structures, including the hippocampus and the hypothalamus $(34,42)$, and has been associated with tolerance to persistent

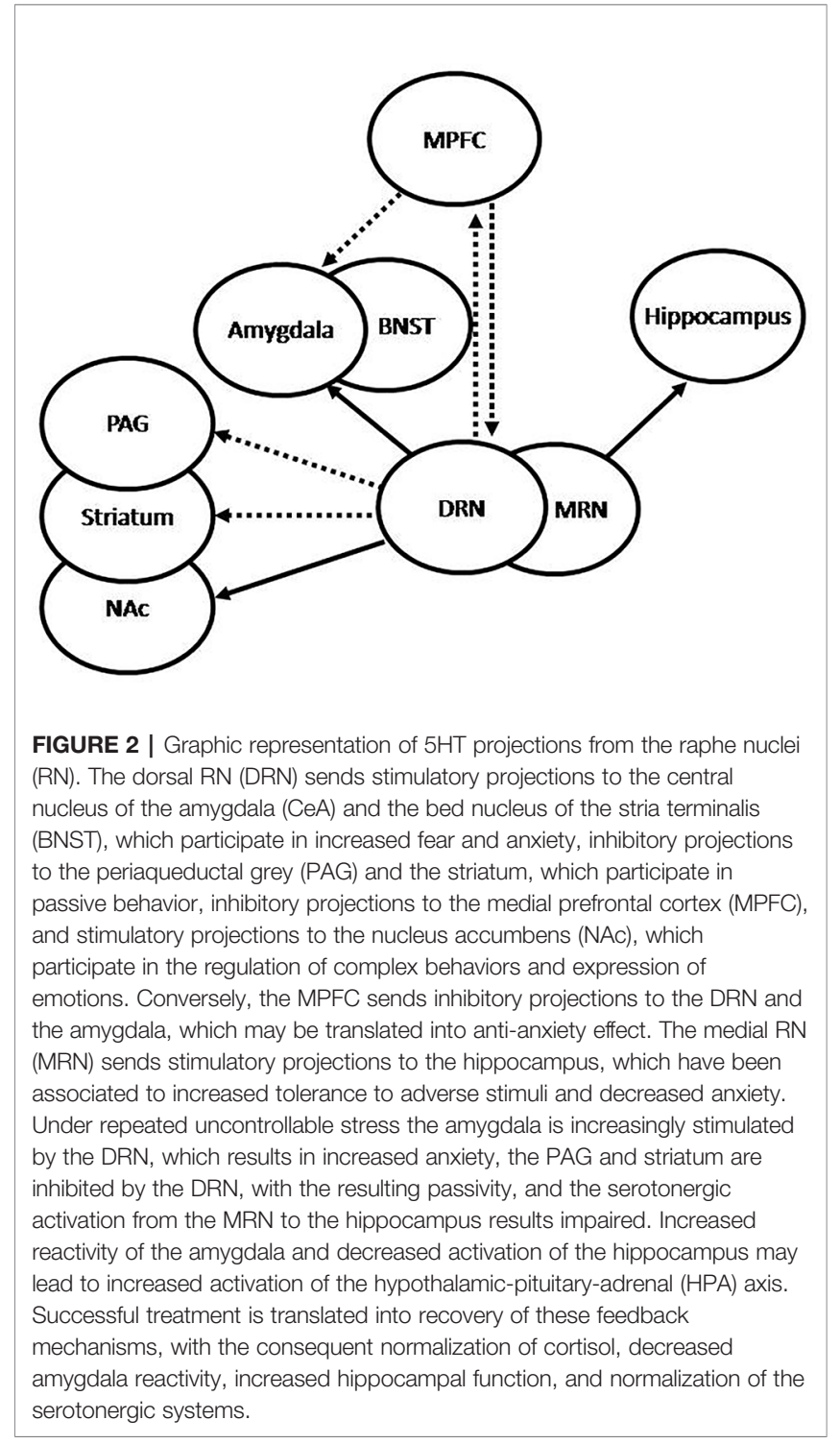

aversive stimuli (43), such as those perceived during chronic stress, and adaptive control on negative emotional experiences (11). Thererfore, dysfunction of this system, particularly involving MRN-hippocampal projections, has been associated with decreased tolerance to aversive stimuli, learned helplessness, and subsequent depression (34). Serotonergic neurons in the RN have also been shown to interact with the noradrenergic and dopaminergic systems (44).

Serotonin (5-hydroxitryptamine, 5HT) released in the synaptic cleft binds to one or more of several $5 \mathrm{HT}$ receptors, classified as $5 \mathrm{HT}_{1 \mathrm{~A}-\mathrm{F}}, 5 \mathrm{HT}_{2 \mathrm{~A}-\mathrm{C}} ; 5 \mathrm{HT}_{3}, 5 \mathrm{HT}_{4}, 5 \mathrm{HT}_{5}, 5 \mathrm{HT}_{6}$, and $5 \mathrm{HT}_{7}$, most of them belonging to a family of $\mathrm{G}$ protein-coupled receptors (GPCRs), with the exception of the $5 \mathrm{HT}_{3}$ receptor, which is a ligand-gated ion channel (45). The $5 \mathrm{HT}_{1 \mathrm{~A}-\mathrm{F}}$ receptor family and the $5 \mathrm{HT}_{5}$ receptor couple with $\mathrm{G}_{\mathrm{i}}$ protein, which inhibits adenylate cyclase (AC) activity, the $5 \mathrm{HT}_{4}, 5 \mathrm{HT}_{6}$, and $5 \mathrm{HT}_{7}$ receptors couple with $\mathrm{G}_{\mathrm{s}}$ protein, which stimulates $\mathrm{AC}$ activation, and the $5 \mathrm{HT}_{2 \mathrm{~A}-\mathrm{C}}$ receptor family couple with $\mathrm{G}_{\mathrm{q}}$ 
protein, which stimulates the activity of phospholipase C (PLC) (46). In addition to the presence of different 5HT receptors, a critical role in the control of serotonergic neurotransmission is exerted by the serotonin transporter (5HTT), which acts to reuptake the remaining $5 \mathrm{HT}$ into the presynaptic terminal, therefore regulating the concentrations of the neurotransmitter in the synaptic cleft. The 5HTT represents the main target of various antidepressants, including the tricyclics (TCs) and the selective serotonin reuptake inhibitors (SSRIs). Blockade of the 5 HTT by these drugs result in increased concentrations of $5 \mathrm{HT}$ in the synaptic cleft, leading in turn to increased activation of $5 \mathrm{HT}$ receptors (47). The efficacy of these antidepressants is associated with adaptive changes produced by its continuous administration, including desensitization or down regulation of somatodendritic $5 \mathrm{HT}_{1 \mathrm{~A}}$ auto-receptors in the $\mathrm{RN}$ (48) and upregulation of post-synaptic $5 \mathrm{HT}_{1 \mathrm{~A}}$ (49), and desensitization of $5 \mathrm{HT}_{2 \mathrm{~A}}$ receptors (50), mostly in the MRN-hippocampal tract. It has been shown that post-synaptic $5 \mathrm{HT}_{1 \mathrm{~A}}$ receptors downregulate or desensitize in different limbic structures by glucocorticoids or exposure to chronic stress (51-53). Cortisol may inhibit 5HT neurotransmission tonically through binding to MRs, while increased levels of cortisol, such as during chronically stressful conditions, bind predominantly to GRs, therefore interacting with GREs and inhibiting the expression of the 5HT1A gene (51). In addition, it has been shown that cortisol may exert a stimulatory effect on 5HT uptake in vitro, which has been attributed to an increased expression of the 5HTT gene by cortisol (54), further supporting the notion of reciprocal regulation between the HPA and 5HT systems, and their potential interactions in the interface between stress and depression.

\section{EFFECTS OF TCAs AND SSRIs IN THE REGULATION OF THE HPA AXIS}

A considerable number of patients suffering with chronic anxiety disorders exhibit hyperactivity of the HPA axis, with the consequent hypercortisolism. This has been described in patients with panic disorder (55) or generalized anxiety disorder $(\mathrm{GAD})(56,57)$, however, hypercortisolism in patients with GAD has not been observed in other studies $(58,59)$. Regarding posttraumatic stress disorder (PTSD), considerable evidence has also revealed alterations of the HPA axis (28). However, patients with PTSD exhibited decreased activity of the HPA axis, which has been attributed to exaggerated negative feedback or hypersecretion of CRH with consequent downregulation of the anterior pituitary CRF receptors (60).

Successful pharmacological approaches often result in normalization of the HPA system. This led to further investigation of the role of the HPA axis in the pathophysiology of these disorders. Because different anti-anxiety agents, including tricyclic antidepressants (TCAs), selective serotonin reuptake inhibitors (SSRIs), and benzodiazepines (BZDs), have been demonstrated in some studies to normalize the HPA axis, various lines of research were developed focusing on the broader spectrum of mechanisms of action underlying the therapeutic effects of these agents.

It has been shown that TCAs and SSRIs, in addition to their well-known pharmacological effects, including blockade of neurotransmitter uptake and subsequent regulation of different pre- and post-synaptic receptors, may also induce significant changes in the HPA axis, associated with their therapeutic effects (61-69). Some of these, at least in part, have been attributed to the potential effect of anti-anxiety agents on transcriptional regulation of different molecules involved in the regulation of the HPA axis (70-74), including GRs, MRs, and CRH. In this regard, it has been proposed that altered GR gene regulation, which may be translated into diminished concentrations of GRs in different neural structures, more specifically hippocampal or hypothalamic GRs, may contribute to deficient feedback of the HPA system (63), which in turn may lead to the consequent alterations observed in patients suffering with depression or chronic anxiety disorders.

Increased GR mRNA expression has been initially observed in vitro, in cell cultures derived from hypothalamus or amygdala, upon incubation in the presence of desipramine or amytriptiline $(70,71)$. Similar results were also observed in studies in which chronic treatment with TCAs, but not short-term treatment, decreases CRH mRNA expression $(61,75,76)$. Similar effects were also observed in vivo with long-term administration of imipramine. In this regard, it has been shown that long-term treatment with this TCA inhibited transcriptional regulation of the $\mathrm{CRH}$ gene, with the consequent decrease of $\mathrm{CRH}$ mRNA expression in the hypothalamus (76), which in turn resulted in a significant reduction in HPA axis activity $(73,76)$.

Regarding SSRIs, in vitro and in vivo studies demonstrated that long-term treatment with fluoxetine increased GR mRNA expression in hippocampal neurons $(77,78)$. More recently, in vivo studies demonstrated that long-term treatment with fluoxetine may also induce functional recovery of hippocampal GRs following chronic stress (79). Moreover, increased hippocampal GRs activation, including phosphorylation and subsequent nuclear translocation, was also observed after longterm treatment with fluoxetine, even in the absence of altered glucocorticoid secretion (79). Although these observations strongly suggest that this mechanism should be involved in the therapeutic effect of fluoxetine, more recent studies have also suggested that additional changes in GRs are not necessary for the behavioral efficacy of the SSRI (80).

It is noteworthy that GRs are expressed in the amygdala, particularly in the CeA (81), where glucocorticoids have been shown to stimulate the expression of CRH in this nucleus (82), in contrast to the inhibitory effect observed in the hypothalamic PVN (83). Cortisol up-regulation of CRH in the amygdala may be translated into activation of the whole system, because $\mathrm{CRH}$ projections from the CeA may exert stimulatory effect on the $\mathrm{PVN}$, hence resulting in increased synthesis and release of $\mathrm{CRH}$ in the hypothalamus, with the consequent hyperactivity of the HPA axis. In this regard, overactivity of the amygdala represents another critical finding, frequently associated with depression and chronic anxiety disorders (84), which has been 
demonstrated in functional imaging studies (85-87). The amygdala has been shown to play a critical role in the physiopathology of anxiety and, as we mentioned previously, it is critically involved in the regulation of the HPA axis, more specifically, through $\mathrm{CRH}$ projections from the CeA, which stimulate the hypothalamic PVN (88). Because the amygdala represents one of the main sources of extra-hypothalamic $\mathrm{CRH}$, hyper-activation of this limbic structure may be reflected in increased concentration of CRH in cerebrospinal fluid (CSF), as observed in many patients with depression (89-91), and elevated $\mathrm{CRH}$ transcript in animal models exposed to chronic stress conditions. Moreover, it was proposed that $\mathrm{CRH}$ overexpression in the $\mathrm{CeA}$ would be a main factor in the origin and development of depression (92). Therefore, a regulatory effect induced by SSRIs, translated into reduced GR and $\mathrm{CRH}$ gene expression in the CeA, may contribute, at least in part, to down regulation of the HPA axis, which is often observed with clinical improvement. In this regard, various studies were performed with escitalopram, which demonstrated that the SSRI was effective in the normalization of different physiopathological parameters related to HPA functioning. According to these studies, escitalopram was effective in reducing elevated concentrations of cortisol in patients with generalized anxiety disorder (GAD), which also was correlated with clinical improvement (93). In addition, escitalopram reversed the adverse effects of $\mathrm{CRH}$ overexpression in the CeA. In vivo studies also revealed that escitalopram was effective in reducing $\mathrm{CRH}$ expression in the hippocampus alongside increased GR expression in the hypothalamus and hippocampus, all associated with significant decreases in HPA axis reactivity (92). More recently, in a preclinical laboratory study, escitalopram inhibited expression of $\mathrm{CRH}$ and its receptors in the hypothalamus (94). The potential effects of TCAs and SSRIs in the regulation of the HPA axis may provide additional knowledge to better understand their therapeutic effects, although further research is necessary in this critical issue.

\section{SIGNALING CASCADES INVOLVED IN THE REGULATION OF GENE EXPRESSION}

In order to understand the molecular mechanisms involved in the long lasting effects of TCAs and SSRIs, various studies were performed focusing on their regulatory effects on different components of the HPA axis. It has been suggested that long lasting effects of TCAs and SSRIs may involve up-regulation of the cAMP-mediated second messenger cascade, which in turn may lead to transcriptional regulation of different genes (95), including $\mathrm{GR}, \mathrm{CRH}$, and BDNF. Binding of different ligands to their specific GPCR are, of course, associated to second messenger cascades. In this regard, stimulation of Gs-coupled receptors may induce the activation of AC, with the consequent synthesis of cAMP, a second messenger responsible for the activation of CAMPdependent protein kinase (PKA) (96). Therefore, stimulation of the AC-cAMP-PKA cascade may be translated into the activation of cAMP response element binding protein (CREB) $(96,97)$, which in turn operates as a transcription factor, mediating the effects of the cAMP cascade. In order to exert its regulatory effect, CREB should be activated, which is attained by phosphorylation at a single serine residue $\left(\mathrm{Ser}^{133}\right)(96,97)$. Once phosphorylated, CREB is able to regulate transcriptional events by binding to an enhancer element, located in the regulatory region of different genes, termed cAMP response element (CRE). It has been shown that phosphorylation of CREB may occur via activation of the AC-cAMP-PKA cascade and also via the calcium-dependent protein kinase (PKC) cascade, which allows CREB to act as a common downstream target of different stimuli, including those mediated by TCAs and SSRIs $(67,95,98,99)$. Molecular alteration of the AC-cAMP-PKA cascade has been described in patients suffering of depression (100), and various studies demonstrated that chronic treatment with different antidepressants contributed to repair this cascade at various molecular levels (101), therefore supporting the critical role played by CREB in the regulation of its target genes in the molecular mechanisms underlying the therapeutic effect of these molecules $(102,103)$. In this regard, it has been shown that the AC-cAMP-PKA cascade plays a critical role in the transcriptional regulation of CRH (104-107). Moreover, it has been shown that transcriptional activation of $\mathrm{CRH}$ depends on cAMP-PKA mediated phosphorylation of CREB, with the subsequent binding to CRE in the promoter region of the $\mathrm{CRH}$ gene (107). Similarly, there is considerable evidence for a cAMP-PKA mediated mechanism involved in GR regulation (108), therefore suggesting potential links between chronic treatment with TCAs and SSRIs, with the subsequent repairing effects on the AC-cAMP-PKA-pCREB cascade, and their regulatory effects on different components of the HPA axis at the transcriptional level.

Various in vivo studies demonstrated that chronic treatment with TCAs or SSRIs may up-regulate the expression of CREB in certain limbic regions (109). In this regard, in vivo studies revealed that chronic treatment with different antidepressants, including serotonin- and norepinephrine-selective reuptake inhibitors, led to increased expression of CREB mRNA in the hippocampus, particularly in CA1 and CA3 pyramidal cells and dentate gyrus granule cells $(109,110)$. In addition, BDNF mRNA expression was also increased in hippocampus after treatment with antidepressants (95), which suggests that chronic treatment with these molecules may lead to up-regulation of CREB, which in turn may increase the expression of different target genes, such as the BDNF gene (109), where a CRE has been described in its promoter region $(111,112)$. Therefore, up-regulation of CREB, with the subsequent increased expression of BDNF, may be critical to counteract the effects of stress on hippocampal neurons $(30,113)$. Moreover, it has been shown that BDNF participates in the regulation of the HPA axis $(114,115)$, which represents a potential link between the AC-cAMP-PKA molecular cascade, with the consequent activation of CREB and BDNF, with its regulatory effect on the HPA axis. Although, this molecular mechanism remains elusive and deserves further research to better understand the potential links between these molecular cascades. Because CREB has been associated with neuronal survival and plasticity in the hippocampus (116) and increased 
expression of CREB in hippocampus has been associated with therapeutic effects, it may represent a potential target for the design of novel therapeutic agents (110).

The therapeutic effect of TCAs and SSRIs has long been associated to up-regulation of $5 \mathrm{HT}_{1 \mathrm{~A}}$ hetero-receptors $(49,117-$ 119), which primarily work via $\mathrm{G}_{\mathrm{i}}$, therefore inhibiting the ACcAMP-PKA signaling cascade. Long-lasting effects of TCAs and SSRIs may involve activation of AC-cAMP-PKA, which in turn requires stimulation of GPCRs associated to $G_{s}$, to activate this signaling cascade. In order to understand this apparent paradox, it is important to take into consideration that $5 \mathrm{HT}_{1 \mathrm{~A}}$ hetero-receptors may activate indirect signaling mechanisms. Among these, it has been shown that activation of $5 \mathrm{HT}_{1 \mathrm{~A}}$, associated to $\mathrm{G}_{\mathrm{i}}$, may exert inhibitory effects on inhibitory pathways. In this regard, the effect of hippocampal $5 \mathrm{HT}_{1 \mathrm{~A}}$ receptors, particularly in the dentate gyrus, has been associated to inhibition of GABAergic interneurons (120). Additional mechanisms have been also proposed, involving other GPCRs, which may also interact with $5 \mathrm{HT}_{1 \mathrm{~A}}$-mediated signaling pathways. In this regard, $5 \mathrm{HT}_{4}$ receptors have been described in different neural structures, including the PFC, amygdala, and hippocampus (121). It has been shown that $5 \mathrm{HT}_{4}$ receptors are associated to $\mathrm{G}_{\mathrm{s}}(122)$ and therefore are known to stimulate the ACcAMP-PKA cascade, with the consequent phosphorylation of CREB. This, in turn, plays a critical role in the synthesis of BDNF, with the resulting facilitation of hippocampal neurogenesis (123, 124). In this regard, activation of $5-\mathrm{HT}_{4}$ receptors have been also associated with the therapeutic effect of SSRIs $(121,125)$, therefore suggesting that potential interactions between $5-\mathrm{HT}_{1 \mathrm{~A}}$ and $5-\mathrm{HT}_{4}$ receptors may be involved in the mechanism of action of antidepressants. Additional mechanisms have been also described involving potential interactions between $5-\mathrm{HT}_{1 \mathrm{~A}}$ and $5-\mathrm{HT}_{7}$ receptors. In this regard, it has been demonstrated that different GPCRs may form homodimers and heterodimers, which may differ in various aspects with the non-associated GPCRs (126). It has been shown that $5 \mathrm{HT}_{1 \mathrm{~A}}$ receptors may form heterodimers with others GPCRs, such as $5 \mathrm{HT}_{7}$, therefore resulting in different effects in comparison to the individual receptor by itself (127). In this regard, $5 \mathrm{HT}_{7}$ receptors have been widely described in different neural structures, including the hippocampus, hypothalamus, PFC, and amygdala $(128,129)$. The $5 \mathrm{HT}_{7}$ receptor is coupled to $\mathrm{G}_{\mathrm{S}}$, therefore its activation results in stimulation of the AC-cAMP-PKA cascade (128). Heterodimerization of $5 \mathrm{HT}_{1 \mathrm{~A}}$ and $5 \mathrm{HT}_{7}$ was observed in vitro (130), where it was shown that co-expression of both GPCRs decreased the activation of inhibitory $\mathrm{G}_{\mathrm{i}}$, mediated by $5 \mathrm{HT}_{1 \mathrm{~A}}$ receptors, without affecting the activation of stimulatory $\mathrm{G}_{S}$, mediated by $5 \mathrm{HT}_{7}$ receptors (130). Therefore, heterodimerization of both GPCRs may lead to important functional changes in their downstream signaling, with the consequent regulatory effects (131).

\section{EFFECTS OF BZDS IN THE REGULATION OF THE HPA AXIS}

The HPA axis is also regulated by other neurotransmitters, including $\gamma$-aminobutyric acid (GABA), the major inhibitory neurotransmitter in the CNS (132). It has been shown to be closely involved in the regulation of hypothalamic function (133-135). Inhibitory GABAergic input has been shown to innervate hypophysiotropic $\mathrm{CRH}$ neurons in the medial parvocellular hypothalamic PVN $(136,137)$ through direct input from peri-PVN sources or indirectly from diverse limbic structures. Direct GABAergic projections may reach the PVN from adjacent hypothalamic nuclei and the BNST (138) or indirectly from various cortical and limbic structures, including the hippocampus, through the ventral subiculum, the amygdala, and the PFC, particularly the ACC, prelimbic, and infralimbic areas (137). Local GABAergic projections to the PVN may in turn be activated or inhibited by glutamatergic or GABAergic projections from cortical and limbic areas, which are closely involved in adaptive responses to stress and, therefore in the regulation of the HPA axis (139). The inhibitory role of the hippocampus in the regulation of the HPA axis is therefore, in part, mediated by GABAergic projections from the ventral subiculum to the PVN, which may allow hippocampal processing, including information related to previous experiences and to the current context, exert adaptive influence on the stress response (137).

At the molecular level, GABAergic effects in the CNS are mediated by two types of postsynaptic receptors, GABA-A and GABA-B (140). The GABA-A receptor is a complex, constituted by diverse sub-units, with specific binding sites for its natural ligand, GABA, benzodiazepines (BZDs), and barbiturates. Upon binding of GABA, activation of postsynaptic GABAA receptors allows the opening of specific chloride $\left(\mathrm{Cl}^{-}\right)$ion channels, with the resulting influx of $\mathrm{Cl}^{-}$and the consequent hyperpolarization of postsynaptic neurons and inhibition of cell firing. Binding of BZDs to their specific site on the GABA-A receptors enhances the binding of GABA to its specific binding-site in the same receptor, which leads to increased frequency of $\mathrm{Cl}^{-}$channels with the resulting hyperpolarization and the consequent inhibition of target neurons $(140,141)$. Therefore, BZDs represent a family of anti-anxiety agents, whose mechanism of action has been associated to their enhancement of GABAergic function in different areas of the CNS, including their potential role in the modulation of the HPA axis, particularly in those patients suffering with depression and anxiety disorders. In this regard, the effect of alprazolam, a potent BZD agonist, has been studied in vivo, where it was observed that both GABA and the BZD exerted inhibitory effect on the HPA axis (141) and, according to previous studies, this effect was attributed to the effect of BZDs on GABAergic receptors inhibiting the CRH system (142). The presence of GABA-A receptors in the hypothalamus further supports this central mechanism of action. Interestingly, diazepam, another well known BZD, have been shown to decrease corticosterone levels in vivo (143) and it has been shown that BZDs decrease cortisol levels in healthy volunteers and depressed patients in a dose-dependent manner $(141,142)$.

This regulatory effect was further studied in vivo with alprazolam, where it was observed that the BZD was capable of inhibiting the HPA axis, and this was attributed to the effect of the BZD on $\mathrm{CRH}$ neurons, which may contribute to its 
therapeutic efficacy (144). The potential role for $\mathrm{CRH}$ in the pathophysiology of anxiety disorders was extensively studied (145), therefore proposing further research on the effects of antianxiety agents on CRH neurotransmission. In this regard, it has been shown that acute treatment with alprazolam decreased CRH concentrations in the LC (146). Moreover, the effect of alprazolam was further studied in vivo, where it was shown to decrease CRH concentrations in the LC after acute or chronic administration (147). The LC receives a rich $\mathrm{CRH}$ innervation (148) contains CRH receptors (149) and is critically involved in the pathophysiology of stress and anxiety disorders (150). Therefore, the effects of alprazolam on hypothalamic $\mathrm{CRH}$ neurons, are likely both direct and indirect through the LC (151). More recently, in vivo studies with lorazepam and clonazepam demonstrated that both BZDs were effective to reversing anxiety-like behavior, including social-avoidance, and these effects were correlated with their inhibitory effect on the HPA axis, mediated by suppression of CRH activity (152). Moreover, it has been shown that both BZDs were effective to reducing stress-induced $\mathrm{CRH}$ mRNA expression in the hypothalamus (152).

According to the molecular mechanisms previously described in the aforementioned section, it has been demonstrated that antianxiety agents, including BZDs, as well as TCAs and SSRIs, may exert certain effects on the HPA axis. However, although this may

\section{REFERENCES}

1. Gold PW, Goodwin FK, Chrousos GP. Clinical and biochemical manifestations of depression. Relation to neurobiology of stress (Parí I). N Engl J Med (1988) 319(6):348-53. doi: 10.1056/NEJM198808113190606

2. Nemeroff CB. The preeminent role of early untoward experience on vulnerability to major psychiatric disorders: The nature-nurture controversy revisited and soon to be resolved. Mol Psychiatry (1999) 4:106-8. doi: 10.1038/ sj.mp. 4000512

3. Nemeroff CB. Neurobiological consequences of childhood trauma. J Clin Psychiatry (2004) 65 Suppl;1:18-28.

4. Heim C, Nemeroff CB. The role of childhood trauma in the neurobiology of mood and anxiety disorders: preclinical and clinical studies. Biol Psychiatry (2001) 49(12):1023-39. doi: 10.1016/S0006-3223(01)01157-X

5. Tafet GE, Bernardini R. Psychoneuroendocrinological links between chronic stress and depression. Prog Neuropsychopharmacol Biol Psychiatry (2003) 27 (6):893-903. doi: 10.1016/S0278-5846(03)00162-3

6. Tafet GE, Nemeroff CB. The links between stress and depression: psychoneuroendocrinological, genetic and environmental interactions. J Neuropsychiat Clin Neurosci (2015). 28(2):77-88. doi: 10.1176/appi. neuropsych.15030053

7. Chrousos GP, Gold PW. The concepts of stress and stress system disorders. Overview of physical and behavioral homeostasis. JAMA (1992) 267(9):124452. doi: 10.1001/jama.267.9.1244

8. López JF, Akil H, Watson SJ. Neural circuits mediating stress. Biol Psychiatry (1999) 46(11):1461-71. doi: 10.1016/S0006-3223(99)00266-8

9. LeDoux JE. Emotion circuits in the brain. Annu Rev Neurosci (2000) 23:155-84. doi: 10.1146/annurev.neuro.23.1.155

10. McEwen BS, Brinton RE. Neuroendocrine aspects of adaptation. Prog Brain Res (1987) 72:11-26. doi: 10.1016/S0079-6123(08)60192-2

11. Smelik PG. Adaptation and brain function. Prog Brain Res (1987) 72:3-9. doi: 10.1016/S0079-6123(08)60191-0

12. LeDoux JE. Brain mechanisms of emotion and emotional leaming. Curr Opin Neurobiol (1992) 2:191-7. doi: 10.1016/0959-4388(92)90011-9 provide further information to better understand the molecular mechanisms involved in their therapeutic effects, it has been shown that these effects only account for a small part of their therapeutic and pharmacological effects, which may be reflected in the partial improvement in the hypercortisolism observed in certain patients suffering depression or anxiety disorders.

\section{CONCLUSION}

The role of the HPA axis in the pathophysiology of depression and chronic anxiety disorders has been extensively studied, including the particular role played by their different components, including $\mathrm{CRH}$ neurotransmission, cortisol, and their specific receptors, and the genes coding for each of these molecules. It remains unclear, however, how important the effects of anti-anxiety agents on the HPA axis activity are in mediating their therapeutics benefits and moreover whether further modulation of $\mathrm{CRH}$ and related systems might augment our currently available agents.

\section{AUTHOR CONTRIBUTIONS}

Both authors contributed equally.

13. LeDoux JE, Iwata J, Cicchetti P, Reis DJ. Different projections of the central amygdaloid nucleus mediate autonomic and behavioral correlates of conditioned fear. J Neurosci (1988) 8:2517-29. doi: 10.1523/JNEUROSCI. 08-07-02517.1988

14. Davis M. The role of the amygdale in fear-potentiated startle: implications for aniumal models of anxiety. TIPS (1992) 13:35-41. doi: 10.1016/0165-6147(92) 90014-W

15. De Kloet ER, Joëls M, Holsboer F. Stress and the brain: from adaptation to disease. Nat Rev Neurosci (2005) 6(6):463-75. doi: 10.1038/nrn1683

16. Drouin J, Sun Y, Chamberland M, Gauthier Y, De Lean A, Nemer M, et al. Novel glucocorticoid receptor complex with DNA element of the hormonerepressed POMC gene. EMBO J (1993) 12:(1):145-56. doi: 10.1002/j.14602075.1993.tb05640.x

17. Malkoski S, Dorin R. Composite glucocorticoid regulation at a functionally defined negative glucocorticoid response element of the human corticotropinreleasing hormone gene. Mol Endocrinol (1999) 13(10):1629-44. doi: 10.1210/ mend.13.10.0351

18. Reul JM, de Kloet ER. Two receptor systems for corticosterone in rat brain: microdistribution and differential occupation. Endocrinology (1985) 117 (6):2505-11. doi: 10.1210/endo-117-6-2505

19. Reul JM, Holsboer F. On the role of corticotropin-releasing hormone receptors in anxiety and depression. Dialog Clin Neurosci (2002) 4(1):31-46.

20. Schaaf MJ, de Jong J, de Kloet ER, Vreugdenhil E. Downregulation of BDNF mRNA and protein in the rat hippocampus by corticosterone. Brain Res (1998) 813(1):112-20. doi: 10.1016/S0006-8993(98)01010-5

21. Murakami S, Imbe H, Morikawa Y, Kubo C, Senba E. Chronic stress, as well as acute stress, reduces BDNF mRNA expression in the rat hippocampus but less robustly. Neurosci Res (2005) 53(2):129-39. doi: 10.1016/j.neures.2005.06.008

22. Arborelius L, Owens MJ, Plotsky PM, Nemeroff CB. The role of corticotropinreleasing factor in depression and anxiety disorders. J Endocrinol (1999) 160 (1):1-12. doi: 10.1677/joe.0.1600001

23. Nestler EJ, Barrot M, DiLeone RJ, Eisch AJ, Gold SJ, Monteggia LM. Neurobiology of depression. Neuron (2002) 34:13-25. doi: 10.1016/S08966273(02)00653-0 
24. Valentino RJ, Foote SL, Page ME. The locus coeruleus as a site for integrating corticotropinreleasing factor and noradrenergic mediation of stress response. Ann N Y Acad Sci (1993) 697:171-87. doi: 10.1111/j.1749-6632.1993.tb49931.x

25. LeDoux JE. The amygdala: contributions to fear and stress. Semin Neurosci (1994) 6:231-7. doi: 10.1006/smns.1994.1030

26. Owens MJ, Nemeroff CB. Physiology and pharmacology of corticotropinreleasing factor. Pharmacol Rev (1991) 43:425-73.

27. Heim C, Newport DJ, Mletzko T, Miller AH, Nemeroff CB. The link between childhood trauma and depression: Insights from HPA axis studies in humans. Psychoneuroendocrinology (2008) 33:693-710. doi: 10.1016/j.psyneuen. 2008.03.008

28. Luca L, Nemeroff CB. The role of the hypothalamic-pituitary-adrenal axis. In: KJ Ressler KJ, Pine DS, Rothbaum BO, editors. Anxiety disorders: translational perspectives on diagnosis and treatment. New York (2014). p. Ch 28: pp 401411.

29. Kaufman J, Plotsky PM, Nemeroff CB, Charney DS. Effects of early adverse experiences on brain structure and function: clinical implications. Biol Psychiatry (2000) 48(8):778-90. doi: 10.1016/S0006-3223(00)00998-7

30. McEwen BS. Stress and hippocampal plasticity. Annu Rev Neurosci (1999) 22:105-22. doi: 10.1146/annurev.neuro.22.1.105

31. Meaney MJ, Szyf M. Environmental programming of stress responses through DNA methylation: life at the interface between a dynamic environment and a fixed genome. Dialog Clin Neurosci (2005) 7:103-23.

32. Azmitia EC. The primate serotonergic system: progression towards a collaborative organization. In: Meltzer H, editor. Psychopharmacology: The third generation of progress. New York: Raven Press Ltd. (1987). p. 61-74.

33. Azmitia EC, Whitaker-Azmitia PM. Anatomy, cell biology, and plasticity of the serotonergic system. Neuropsychopharmacological implications for the actions of psychotropic drugs. In: Bloom FE, Kupfer DJ, editors. Psychopharmacology: The fourth generation of progress. New York: Raven Press Ltd. (1995). p. 443-9.

34. Deakin JFW. Distinct roles of 5HT subsystems in panic, anxiety and depression. In: Racagni G, Brunello N, Fukuda T, editors. Biol. Psych, vol. 1 . Amsterdam: Elsevier (1991). p. 305-7.

35. Lowry CA, Johnson PL, Hay-Schmidt A, Mikkelsen J, Shekhar A. Modulation of anxiety circuits by serotonergic systems. Stress (2005) 8(4):233-46. doi: $10.1080 / 10253890500492787$

36. Petrov T, Krukoff TL, Jhamandas JH. Chemically defined collateral projections from the pons to the central nucleus of the amygdala and hypothalamic paraventricular nucleus in the rat. Cell Tissue Res (1994) 277 (2):289-95. doi: 10.1007/BF00327776

37. Commons KG, Connolley KR, Valentino RJ. A neurochemically distinct dorsal raphe-limbic circuit with a potential role in affective disorders. Neuropsychopharmacology (2003) 28(2):206-15. doi: 10.1038/sj.npp.1300045

38. Van Bockstaele EJ, Biswas A, Pickel VM. Topography of serotonin neurons in the dorsal raphe nucleus that send axon collaterals to the rat prefrontal cortex and nucleus accumbens. Brain Res (1993) 624:188-98. doi: 10.1016/0006-8993 (93) $90077-Z$

39. Stezhka VV, Lovick TA. Projections from dorsal raphe nucleus to the periaqueductal grey matter: studies in slices of rat midbrain maintained in vitro. Neurosci Lett (1997) 230:57-60. doi: 10.1016/S0304-3940(97)00464-3

40. Bandler R, Keay KA, Floyd N, Price J. Central circuits mediating patterned autonomic activity during active vs. passive emotional coping. Brain Res Bull (2000) 53:95-104. 28. doi: 10.1016/s0361-9230(00)00313-0

41. Abramson LY, Seligman M, Teasdale LD. Learned helplessness in humans: critique and reformulation. J Abnorm Psychol (1978) 87:49-78. doi: 10.1037/ 0021-843X.87.1.49

42. Hensler JG. Serotonergic modulation of the limbic system. Neurosci Biobehav Rev (2006) 30:203-14. doi: 10.1016/j.neubiorev.2005.06.007

43. Kennett GA, Dickinson SL, Curzon G. Enhancement of some 5-HTdependent behavioural responses following repeated immobilization in rats. Brain Res (1985) 330(2):253-63. doi: 10.1016/0006-8993(85)90684-5

44. Ordway GA, Klimek V, Mann JJ. Neurocircuitry of mood disorders. In: Davis KL, Charney D, Coyle JT, Nemeroff CB, editors. Psychopharmacology: The Fifth Generation of Progress. Philadelphia: Lippincott, Williams, \& Wilkins (2002). p. 1051-64.

45. Albert PR, Tiberi M. Receptor signaling and structure: insights from serotonin-1 receptors. Trends Endocrinol Metab (2001) 12(10):453-60. doi: $10.1016 /$ S1043-2760(01)00498-2
46. Giulietti M, Vivenzio V, Piva F, Principato G, Bellantuono C, Nardi B. How much do we know about the coupling of G-proteins to serotonin receptors? Mol Brain (2014) 7:49. doi: 10.1186/s13041-014-0049-y

47. Schloss P, Williams DC. The serotonin transporter: a primary target for antidepressant drugs. J Psychopharmacol (1998) 12(2):115-21. doi: 10.1177/ 026988119801200201

48. Blier S, de Montigny C. Current advances and trends in the treatment of depression. Trends Pharmacol Sci (1994) 15:220-6. doi: 10.1016/0165-6147 (94) $90315-8$

49. Blier P, de Montigny C, Chaput Y. Modifications of the serotonin system by antidepressant treatments: implications for the therapeutic response in major depression. J Clin Psychopharmacol (1987) 7:24S-35S. doi: 10.1097/00004714198712001-00003

50. Yamauchi M, Miyara T, Matsushima T, Imanishi T. Desensitization of 5-HT2A receptor function by chronic administration of selective serotonin reuptake inhibitors. Brain Res (2006) 1067(1):164-9. doi: 10.1016/j.brainres.2005.10.075

51. Lopez JF, Chalmers DT, Little KY, Watson SJ. Regulation of serotonin1A, glucocorticoid, and mineralocorticoid receptor in rat and human hippocampus: implications for the neurobiology of depression. Biol Psychiat (1998) 43:547-73. doi: 10.1016/S0006-3223(97)00484-8

52. Karten YJ, Nair SM, van Essen L, Sibug R, Joels M. Long-term exposure to high corticosterone levels attenuates serotonin responses in rat hippocampal CA1 neurons. Proc Natl Acad Sci USA (1999) 96:13456-61. doi: 10.1073/ pnas.96.23.13456

53. van Riel E, van Gemert NG, Meijer OC, Joels M. Effect of early life stress on serotonin responses in the hippocampus of young adult rats. Synapse (2004) 53:11-9. doi: 10.1002/syn.20033

54. Tafet GE, Toister-Achituv M, Shinitzky M. Enhancement of serotonin uptake by cortisol: a possible link between stress and depression. Cognit Affect Behav Neurosci (2001a) 1(1):96-104. doi: 10.3758/CABN.1.1.96

55. Abelson JL, Khan S, Liberzon I, Young EA. HPA axis activity in patients with panic disorder: review and synthesis of four studies. Depress Anxiety (2007) 24 (1):66-76. doi: 10.1002/da.20220

56. Tafet GE, Idoyaga-Vargas VP, Abulafia DP, Calandria JM, Roffman SS, Chiovetta A, et al. Correlation between cortisol level and serotonin uptake in patients with chronic stress and depression. Cognit Affect Behav Neurosci (2001b) 1(4):388-93. doi: 10.3758/CABN.1.4.388

57. Risbrough VB, Stein MB. Role of corticotropin releasing factor in anxiety disorders: a translational research perspective. Horm Behav (2006) 50(4):55061. doi: 10.1016/j.yhbeh.2006.06.019

58. Martin EI, Nemeroff CB. The biology of generalized anxiety disorder and major depressive disorder: commonalities and distinguishing features. In: Goldberg D, Kendler KS, Sirovatka PJ, Regier DA, editors. Arlington, VA, USA: American Psychiatric Association (2010). p. 45-70.

59. Hek K, Direk N, Newson RS, Hofman A, Hoogendijk WJ, Mulder CL, et al. Anxiety disorders and salivary cortisol levels in older adults: a populationbased study. Psychoneuroendocrinology (2013) 38(2):300-5. doi: 10.1016/ j.psyneuen.2012.06.006

60. Yehuda R, Golier JA, Halligan SL, Meaney M, Bierer LM. The ACTH response to dexamethasone in PTSD. Am J Psychiatry (2004) 161(8):1397-403. doi: 10.1176/appi.ajp.161.8.1397

61. Brady LS, Whitfield HJ, Fox RJ, Gold PW, Herkenham M. Long-term antidepressant administration alters corticotropin-releasing hormone, tyrosine hydroxylase and mineralicorticoid receptor gene expression in rat brain: therapeutic implications. J Clin Invest (1991) 87:831-7. doi: 10.1172/JCI115086

62. Brady LS, Gold PW, Herkenham M, Lynn AB, Whitfield HJ. The antidepressants fluoxetine, idosoxan, and phenelzine alter corticotropinreleasing hormone and tyrosine hydroxylase mRNA levels in rat brain: therapeutic implications. Brain Res (1992) 572:117-25. 10. doi: 10.1016/ 0006-8993(92)90459-m

63. Barden N, Reul J, Holsboer F. Do antidepressants stabilize mood through actions on the hypothalamic-pituitary-adrenocortical system? Trends Neurosci (1995) 18(1):6-11. doi: 10.1016/0166-2236(95)93942-Q

64. Barden N. Implication of the hypothalamic-pituitary-adrenal axis in the physiopathology of depression. J Psychiatry Neurosci (2004) 29(3):185-93.

65. Holsboer F, Barden N. Antidepressants and Hypothalamic-PituitaryAdrenocortical Regulation. Endocrine Rev (1996) 17(2):187.204. doi: 10.1210/edrv-17-2-187 
66. Holsboer F. Neuroendocrinology of mood disorders. In: BloomFE, Kupfer DJ, editor. Psychopharmacology: The fourth generation of progress. New York: Raven Press Ltd. (1995). p. 957-69.

67. Holsboer F. The coríicosteroid hypothesis of depression. Neuropsychopharmacology (2000) 23(5):477-501. doi: 10.1016/S0893-133X (00)00159-7

68. Budziszewska B. Effect of antidepressant drugs on the hypothalamic-pituitaryadrenal axis activity and glucocorticoid receptor function. Pol J Pharmacol (2002) 54(4):343-9.

69. Nikisch G. Involvement and role of antidepressant drugs of the hypothalamicpituitary-adrenal axis and glucocorticoid receptor function. Neuro Endocrinol Lett (2009) 30(1):11-6.

70. Pepin MC, Beaulieu S, Barden N. Antidepressants regulate glucocorticoid receptor messenger RNA concentrations in primary neuronal cultures. Brain Res Mol Brain Res (1989) 6(1):77-83. doi: 10.1016/0169-328X(89)90031-4

71. Pepin MC, Govindan MV, Barden N. Increased glucocorticoid receptor gene promoter activity after antidepressant treatment. Mol Pharmacol (1992) 41 (6):1016-22.

72. Barden N. Modulation of glucocorticoid receptor gene expression by antidepressant drugs. Pharmacopsychiatry (1996) 29(1):12-22. doi: 10.1055/ s-2007-979536

73. Heydendael W, Jacobson L. Differential effects of imipramine and phenelzine on corticosteroid receptor gene expression in mouse brain: potential relevance to antidepressant response. Brain Res (2008) 1238:93-107. doi: 10.1016/ j.brainres.2008.08.018

74. Heydendael W, Jacobson L. Widespread hypothalamic-pituitaryadrenocortical axis-relevant and mood-relevant effects of chronic fluoxetine treatment on glucocorticoid receptor gene expression in mice. Eur J Neurosci (2010) 31(5):892-902. doi: 10.1111/j.1460-9568.2010.07131.x

75. Melia KR, Nestler EJ, Dunnan RS. Chronic imipramine treatment normalizes levels of tyrosine hydroxylase in the locus coeruleus of chronically stressed rats. Psychopharmacology (1992) 108:23-6. doi: 10.1007/BF02245280

76. Michelson D, Galliven E, Hill L, Demitrack M, Chrousos G, Gold P. Chronic imipramine is associated with diminished hypothalamic-pituitary-adrenal axis responsivity in healthy humans. J Clin Endocrinol Metab (1997) 82 (8):2601-6. doi: 10.1210/jcem.82.8.4172

77. Lai M, McCormick JA, Chapman KE, Kelly PA, Seckl JR, Yau JL. Differential regulation of corticosteroid receptors by monoamine neurotransmitters and antidepressant drugs in primary hippocampal culture. Neuroscience (2003) 118(4):975-84. doi: 10.1016/S0306-4522(03)00038-1

78. Yau JL, Noble J, Chapman KE, Seckl JR. Differential regulation of variant glucocorticoid receptor mRNAs in the rat hippocampus by the antidepressant fluoxetine. Brain Res Mol Brain Res (2004) 129(1-2):189-92. doi: 10.1016/ j.molbrainres.2004.06.033

79. Lee MS, Kim YH, Park WS, Park OK, Kwon SH, Hong KS, et al. Temporal variability of glucocorticoid receptor activity is functionally important for the therapeutic action of fluoxetine in the hippocampus. Mol Psychiatry (2016) 21 (2):252-60. doi: 10.1038/mp.2014.137

80. Simard S, Shail P, MacGregor J, El Sayed M, Duman RS, Vaccarino FM, et al. Fibroblast growth factor 2 is necessary for the antidepressant effects of fluoxetine. PloS One (2018) 13(10):e0204980. doi: 10.1371/journal.pone. 0204980

81. Herman JP. Regulation of adrenocorticosteroid receptor mRNA expression in the central nervous system. Cell Mol Neurobiol (1993) 13(4):349-72. doi: 10.1007/BF00711577

82. Makino S, Gold PW, Schulkin J. Effects of corticosterone on CRH mRNA and content in the bed nucleus of the stria terminalis; comparison with the effects in the central nucleus of the amygdala and the paraventricular nucleus of the hypothalamus. Brain Res (1994) 657(12):141-9. doi: 10.1016/0006-8993(94) 90961-X

83. Beyer HS, Matta SG, Sharp BM. Regulation of the messenger ribonucleic acid for corticotropin-releasing factor in the paraventricular nucleus and other brain sites of the rat. Endocrinology (1988) 123(4):2117-23. doi: 10.1210/ endo-123-4-2117

84. Flandreau EI, Ressler KJ, Owens MJ, Nemeroff CB. Chronic overexpression of corticotropinreleasing factor from the central amygdala produces HPA axis hyperactivity and behavioral anxiety associated with gene-expression changes in the hippocampus and paraventricular nucleus of the hypothalamus.
Psychoneuroendocrinology (2012) 37(1):27-38. doi: 10.1016/j.psyneuen. 2011.04.014

85. Drevets WC. Neuroimaging abnormalities in the amygdala in mood disorders. Ann N Y Acad Sci (2003) 985:420-44. doi: 10.1111/j.1749-6632.2003. tb07098.x

86. Pfleiderer B, Zinkirciran S, Arolt V, Heindel W, Deckert J, Domschke K. fMRI amygdala activation during a spontaneous panic attack in a patient with panic disorder. World J Biol Psychiatry (2007) 8(4):269-72. doi: 10.1080/ 15622970701216673

87. Rauch SL, Shin LM, Wright CI. Neuroimaging studies of amygdala function in anxiety disorders. Ann N Y Acad Sci (2003) 985:389-410. doi: 10.1111/j.17496632.2003.tb07096.x

88. Hsu DT, Chen FL, Takahashi LK, Kalin NH. Rapid stress-induced elevations in corticotropinreleasing hormone mRNA in rat central amygdala nucleus and hypothalamic paraventricular nucleus: an in situ hybridization analysis. Brain Res (1998) 788(1-2):305-10. doi: 10.1016/S0006-8993(98)00032-8

89. Banki CM, Karmacsi L, Bissette G, Nemeroff CB. CSF corticotropin-releasing hormone and somatostatin in major depression: response to antidepressant treatment and relapse. Eur Neuropsychopharmacol (1992) 2(2):107-13. doi: 10.1016/0924-977X(92)90019-5

90. Fossey MD, Lydiard RB, Ballenger JC, Laraia MT, Bissette G, Nemeroff CB. Cerebrospinal fluid corticotropin-releasing factor concentrations in patients with anxiety disorders and normal comparison subjects. Biol Psychiatry (1996) 39(8):703-7. doi: 10.1016/0006-3223(95)00197-2

91. Nemeroff CB, Widerlöv E, Bissette G, Walléus H, Karlsson I, Eklund K, et al. Elevated concentrations of CSF corticotropin-releasing factor-like immunoreactivity in depressed patients. Science (1984) 226(4680):1342-4. doi: $10.1126 /$ science. 6334362

92. Flandreau EI, Bourke CH, Ressler KJ, Vale WW, Nemeroff CB, Owens MJ. Escitalopram alters gene expression and HPA axis reactivity in rats following chronic overexpression of corticotropin-releasing factor from the central amygdala. Psychoneuroendocrinology (2013) 38(8):1349-61. doi: 10.1016/ j.psyneuen.2012.11.020

93. Lenze EJ, Mantella RC, Shi P, Goate AM, Nowotny P, Butters MA, et al. Elevated cortisol in older adults with generalized anxiety disorder is reduced by treatment: a placebo-controlled evaluation of escitalopram. Am J Geriatr Psychiatry (2011) 19(5):482-90. doi: 10.1097/JGP.0b013e3181ec806c

94. Benatti C, Alboni S, Blom JMC, Mendlewicz J, Tascedda F, Brunello N. Molecular changes associated with escitalopram response in a stress-based model of depression. Psychoneuroendocrinology (2018) 87:74-82. doi: 10.1016/j.psyneuen.2017.10.011

95. Thome J, Sakai N, Shin K, Steffen C, Zhang YJ, Impey S, et al. cAMP response element-mediated gene transcription is upregulated by chronic antidepressant treatment. J Neurosci (2000) 20(11):4030-6. doi: 10.1523/JNEUROSCI.20-1104030.2000

96. Montminy MR, Gonzalez GA, Yamamoto KK. Regulation of cAMP-inducible genes by CREB. Trends Neurosci (1990) 13(5):184-8. doi: 10.1016/0166-2236 (90)90045-C

97. Meyer TE, Habener JF. Cyclic adenosine $3^{\prime}, 5^{\prime}$-monophosphate response element binding protein (CREB) and related transcription-activating deoxyribonucleic acid-binding proteins. Endocr Rev (1993) 14(3):269-90. doi: 10.1210/edrv-14-3-269

98. Duman RS, Heninger GR, Nestler EJ. A molecular and cellular theory of depression. Arch Gen Psychiatry (1997) 54:597-606. doi: 10.1001/ archpsyc.1997.01830190015002

99. Duman RS, Malberg J, Thome J. Neural plasticity to stress and antidepressant treatment. Biol Psychiatry (1999) 46:1181-91. doi: 10.1016/S0006-3223(99) 00177-8

100. Shelton RC, Manier DH, Sulser F. cAMP-dependent protein kinase activity in major depression. A J Psych (1996) 153(8):1037-42. doi: 10.1176/ ajp.153.8.1037

101. Nestler EJ, Terwilliger RZ, Duman RS. Chronic antidepressant administration alters the subcellular distribution of cyclic AMP-dependent protein kinase in rat frontal cortex. J Neurochem (1989) 53(5):1644-7. doi: 10.1111/j.1471-4159.1989.tb08564.x

102. Shaywitz AJ, Greenberg ME. CREB: a stimulus induced transcription factor activated by a diverse array of extracellular signals. Ann Rev Biochem (1999) 68:821-61. doi: 10.1146/annurev.biochem.68.1.821 
103. Duman RS, Malberg J, Nakagawa S, D'Sa C. Neuronal plasticity and survival in mood disorders. Biol Psychiatry (2000) 48(8):732-9. doi: 10.1016/S00063223(00)00935-5

104. Aguilera G, Liu Y. The molecular physiology of CRH neurons. Front Neuroendocrinol (2012) 33(1):67-84. doi: 10.1016/j.yfrne.2011.08.002

105. Adler GK, Smas CM, Fiandaca M, Frim DM, Majzoub JA. Regulated expression of the human corticotropin releasing hormone gene by cyclic AMP. Mol Cell Endocrinol (1990) 70:165-74. doi: 10.1016/0303-7207(90) 90156-3

106. Liu Y, Kamitakahara A, Kim AJ, Aguilera G. Cyclic adenosine $3^{\prime}, 5^{\prime}-$ monophosphate responsive element binding protein phosphorylation is required but not sufficient for activation of corticotropin-releasing hormone transcription. Endocrinology (2008) 149:3512-20. doi: 10.1210/ en.2008-0052

107. Seasholtz AF, Thompson RC, Douglass JO. Identification of a cyclic adenosine monophosphateresponsive element in the rat corticotropinreleasing hormone gene. Mol Endocrinol (1988) 2:1311-9. doi: 10.1210/ mend-2-12-1311

108. Anacker C, Zunszain PA, Carvalho LA, Pariante CM. The glucocorticoid receptor: Pivot of depression and of antidepressant treatment? Psychoneuroendocrinology (2011) 36(3):415-25. doi: 10.1016/j.psyneuen.2010.03.007

109. Nibuya M, Nestler EJ, Duman RS. Chronic Antidepressant Administration Increases the Expression of CAMP Response Element Binding Protein (CREB) in Rat Hippocampus. J Neurosci (1996) 16(7):2365-72. doi: 10.1523/JNEUROSCI.16-07-02365.1996

110. Chen AC, Shirayama Y, Shin KH, Neve RL, Duman RS. Expression of the cAMP response element binding protein (CREB) in hippocampus produces an antidepressant effect. Biol Psychiatry (2001) 49(9):753-62. doi: 10.1016/ S0006-3223(00)01114-8

111. Shieh PB, Hu SC, Bobb K, Timmusk T, Gosh A. Identification of a signaling pathway involved in calcium regulation of BDNF expression. Neuron (1998) 20:727-40. doi: 10.1016/S0896-6273(00)81011-9

112. Tao X, Finkbeiner S, Arnold DB, Shaywitz AJ, Greenberg ME. $\mathrm{Ca}^{2+}$ influx regulates BDNF transcription by a CREB family transcription factordependent mechanism. Neuron (1998) 20:709-26. doi: 10.1016/S0896-6273 (00)81010-7

113. Sapolsky RM. Stress, glucocorticoids, and damage to the nervous system: the current state of confusion. Stress (1996) 1:1-19. doi: 10.3109/ 10253899609001092

114. Givalois L, Naert G, Rage F, Ixart G, Arancibia S, Tapia-Arancibia L. A single brain-derived neurotrophic factor injection modifies hypothalamo-pituitaryadrenocortical axis activity in adult male rats. Mol Cell Neurosci (2004) 27:280-95. doi: 10.1016/j.mcn.2004.07.002

115. Naert G, Ixart G, Maurice T, Tapia-Arancibia L, Givalois L. Brain-derived neurotrophic factor and hypothalamic-pituitary-adrenal axis adaptation processes in a depressive-like state induced by chronic restraint stress. Mol Cell Neurosci (2011) 46(1):55-66. doi: 10.1016/j.mcn.2010.08.006

116. Nakagawa S, Kim JE, Lee R, Malberg JE, Chen J, Steffen C, et al. Regulation of neurogenesis in adult mouse hippocampus by cAMP and the cAMP response element-binding protein. J Neurosci (2002) 22(9):3673-82. doi: 10.1523/ JNEUROSCI.22-09-03673.2002

117. Savitz J, Lucki I, Drevets WC. 5-HT(1A) receptor function in major depressive disorder. Prog Neurobiol (2009) 88(1):17-31. doi: 10.1016/ j.pneurobio.2009.01.009

118. Miller JM, Hesselgrave N, Ogden RT, Zanderigo F, Oquendo MA, Mann JJ, et al. Brain serotonin 1A receptor binding as a predictor of treatment outcome in major depressive disorder. Biol Psychiatry (2013) 74(10):7607. doi: 10.1016/j.biopsych.2013.03.021

119. Kaufman J, DeLorenzo C, Choudhury S, Parsey RV. The 5-HT1A receptor in Major Depressive Disorder. Eur Neuropsychopharmacol (2016) 26(3):397410. doi: 10.1016/j.euroneuro.2015.12.039

120. Polter AM, Li X. 5-HT1A receptor-regulated signal transduction pathways in brain. Cell Signal (2010) 22(10):1406-12. doi: 10.1016/j.cellsig.2010.03.019

121. Samuels BA, Mendez-David I, Faye C, David SA, Pierz KA, Gardier AM, et al. Serotonin 1A and Serotonin 4 Receptors: Essential Mediators of the Neurogenic and Behavioral Actions of Antidepressants. Neuroscientist (2016) 22(1):26-45. doi: 10.1177/1073858414561303
122. Yohn CN, Gergues MM, Samuels BA. The role of 5-HT receptors in depression. Mol Brain (2017) 10(1):28. doi: 10.1186/s13041-017-0306-y

123. Duman RS, Malberg J, Nakagawa S. Regulation of adult neurogenesis by psychotropic drugs and stress. J Pharmacol Exp Ther (2001) 299(2):401-7.

124. Castrén E. Neurotrophins and psychiatric disorders. Handb Exp Pharmacol (2014) 220:461-79. doi: 10.1007/978-3-642-45106-5_17

125. Schmidt EF, Warner-Schmidt JL, Otopalik BG, Pickett SB, Greengard P, Heintz N. Identification of the cortical neurons that mediate antidepressant responses. Cell (2012) 149(5):1152-63. doi: 10.1016/j.cell.2012.03.038

126. Milligan G. G protein-coupled receptor dimerisation: molecular basis and relevance to function. Biochim Biophys Acta (2007) 1768:825-35. doi: 10.1016/j.bbamem.2006.09.021

127. Rojas PS, Fiedler JL. What Do We Really Know About 5-HT1A Receptor Signaling in Neuronal Cells? Front Cell Neurosci (2016) 10:272. doi: 10.3389/ fncel.2016.00272

128. Leopoldo M, Lacivita E, Berardi F, Perrone R, Hedlund PB. Serotonin 5- $\mathrm{HT}_{7}$ receptor agents: structure-activity relationships and potential therapeutic applications in central nervous system disorders. Pharmacol Ther (2011) 129 (2):120-48. doi: 10.1016/j.pharmthera.2010.08.013

129. Volpicelli F, Speranza L, di Porzio U, Crispino M, Perrone-Capano C. The serotonin receptor 7 and the structural plasticity of brain circuits. Front Behav Neurosci (2014) 8:318. doi: 10.3389/fnbeh.2014.00318

130. Renner U, Zeug A, Woehler A, Niebert M, Dityatev A, Dityateva G, et al. Heterodimerization of serotonin receptors 5-HT1A and 5-HT7 differentially regulates receptor signalling and trafficking. J Cell Sci (2012) (Pt 10):248699.. doi: $10.1242 /$ jcs. 101337

131. Crispino M, Volpicelli F, Perrone-Capano C. Role of the Serotonin Receptor 7 in Brain Plasticity: From Development to Disease. Int J Mol Sci (2020) 21 (2):505-23. doi: 10.3390/ijms21020505

132. Roberts E. Disinhibition as an organizing principle in the nervous system: the role of the GABA system. In: Roberts E, Chase TN, Tower DB, editors. GABA in nervous system function. New York: Raven (1976). p. 515-39.

133. Herman JP, Cullinan WE. Neurocircuitry of stress: central control of the hypothalamopituitary-adrenocortical axis. Trends Neurosci (1997) 20:78-84. doi: 10.1016/S0166-2236(96)10069-2

134. Herman JP, Cullinan WE, Ziegler DR, Tasker JG. Role of the paraventricular nucleus microenvironment in stress integration. Eur J Neurosci (2002) 16:381-5. doi: 10.1046/j.1460-9568.2002.02133.x

135. Herman JP, Mueller NK, Figueiredo H. Role of GABA and Glutamate Circuitry in Hypothalamo-Pituitary-Adrenocortical Stress Integration. Ann N Y Acad Sci (2004) 1018:35-45. doi: 10.1196/annals.1296.004

136. Miklos IH, Kovacs KJ. GABAergic innervation of corticotropinreleasing hormone $(\mathrm{CRH})$ secreting parvocellular neurons and its plasticity as demonstrated by quantitative immunoelectron microscopy. Neuroscience (2002) 113:581-92. doi: 10.1016/S0306-4522(02)00147-1

137. Cullinan WE, Ziegler DR, Herman JP. Functional role of local GABAergic influences on the HPA axis. Brain Struct Funct (2008) 213:63-72. doi: 10.1007/s00429-008-0192-2

138. Cullinan WE, Herman JP, Watson SJ. Ventral subicular interaction with the hypothalamic paraventricular nucleus: evidence for a relay in the bed nucleus of the stria terminalis. J Comp Neurol (1993) 332:1-20. doi: 10.1002/ cne. 903320102

139. Herman JP, Mueller NK. Role of the ventral subiculum in stress integration. Behav Brain Res (2006) 174:215-24. doi: 10.1016/j.bbr.2006.05.035

140. Bowery NG, Hill DR, Hudson AL, Price GW, Turnbull WJ, Wilkin GP. Heterogeneity of mammalian GABA receptors. In: Bowery NG, editor. Actions and Interactions of GABA and Benzodiazepine. NY: Raven (1984). p. 81108 .

141. Calogero AE, Gallucci WT, Chrousos GP, Gold PW. Interaction between GABAergic neurotransmission and rat hypothalamic corticotropin-releasing hormone secretion in vitro. Brain Res (1988) 463:28-36. doi: 10.1016/00068993(88)90523-9

142. Gram LF, Christensen P. Benzodiazepine suppression of cortisol secretion: a measure of anxiolytic activity? Pharmacopsychiatry (1986) 19:19-22. doi: $10.1055 / \mathrm{s}-2007-1017143$

143. Bizzi A, Ricci MR, Veneroni E, Amato M, Garaitini S. Benzodiazepine receptor antagonists reverse the effect of diazepam on plasma corticosterone 
in stressed rats. J Pharm Pharmacol (1984) 36:134-13. doi: 10.1111/j.20427158.1984.tb03014.x

144. Kalogeras KT, Calogero AE, Kuribayiashi T, Khan I, Gallucci WT, Kling MA, et al. In vitro and in vivo effects of the triazolobenzodiazepine alprazolam on hypothalamic-pituitary-adrenal function: pharmacological and clinical implications. J Clin Endocrinol Metab (1990) 70(5):1462-71. doi: 10.1210/ jcem-70-5-1462

145. Nemeroff CB. New vistas in neuropeptide research: focus on corticotropinreleasing factor. Neuro Psychopharmacol (1992) 6:787-94.

146. Owens MJ, Bissette G, Nemeroff CB. Acute effects of alprazolam and adinazolam on the concentrations of corticotropin-releasing factor in the rat brain. Synapse (1989) 4:196-202. doi: 10.1002/syn.890040304

147. Owens MJ, Vargas MA, Knight DL, Nemeroff CB. The effects of alprazolam on corticotropinreleasing factor neurons in the rat brain: acute time course, chronic treatment and abrupt withdrawal. J Pharmacol Exp Ther (1991) 258 (1):349-56.

148. Cummings S, Elde R, Ells J, Lindall A. Corticotropin-releasing factor immunoreactivity is widely distributed within the central nervous system of the rat: an immunohistochemical study. J Neurosci (1983) 3(7):1355-68. doi: 10.1523/JNEUROSCI.03-07-01355.1983

149. De Souza EB, Insel TR, Perrin MH, Rivier J, Vale WW, Kuhar MJ. Corticotropin-releasing factor receptors are widely distributed within the rat central nervous system: an autoradiographic study. J Neurosci (1985) 5 (12):3189-203. doi: 10.1523/JNEUROSCI.05-12-03189.1985

150. Bloom FE. Norepinephrinc mediated synaptic transmission and hypotheses of psychiatric disorders. In: III Meyer E, Brady JV, editors. Research in the psychobiology of human behavior. Baltimore: The Johns Hopkins University Press (1979). p. $11 \mathrm{I}$.

151. Owens MJ, Vargas MA, Nemeroff CB. The effects of alprazolam on corticotropin-releasing factor neurons in the rat brain: implications for a role for CRF in the pathogenesis of anxiety disorders. J Psychiatr Res (1993) 27(Suppl 1):209-20. doi: 10.1016/0022-3956(93)90029-2

152. Ramirez K, Niraula A, Sheridan JF. GABAergic modulation with classical benzodiazepines prevent stress-induced neuro-immune dysregulation and behavioral alterations. Brain Behav Immun (2016) 51:154-68. doi: 10.1016/ j.bbi.2015.08.011

Conflict of Interest: CN's disclosures: Research/Grants: National Institutes of Health (NIH); Consulting (last three years): Xhale, Takeda, Taisho Pharmaceutical Inc.,Signant Health, Sunovion Pharmaceuticals Inc., Janssen Research \& Development LLC, Magstim, Inc., Navitor Pharmaceuticals, Inc., TC MSO, Inc., Intra-Cellular Therapies, Inc., EMA Wellness, Gerson Lehrman Group (GLG), Acadia Pharmaceuticals; Stockholder: Xhale, Celgene, Seattle Genetics, Abbvie, OPKO Health, Inc., Antares, BI Gen Holdings, Inc., Corcept Therapeutics Pharmaceuticals Company, TC MSO, Inc., Trends in Pharma Development, LLC, EMA Wellness; Scientific Advisory Boards: American Foundation for Suicide Prevention (AFSP), Brain and Behavior Research Foundation (BBRF), Xhale, Anxiety Disorders Association of America (ADAA), Skyland Trail, Signant Health, Laureate Institute for Brain Research (LIBR), Inc.; Board of Directors: Gratitude America, ADAA, Xhale Smart, Inc.; Income sources or equity of $\$ 10,000$ or more: American Psychiatric Publishing, Xhale, Signant Health, CME Outfitters, Intra-Cellular Therapies, Inc., Magstim, EMA Wellness; Patents: Method and devices for transdermal delivery of lithium (US 6,375,990B1) Method of assessing antidepressant drug therapy via transport inhibition of monoamine neurotransmitters by ex vivo assay (US 7,148,027B2) Compounds, Compositions, Methods of Synthesis, and Methods of Treatment (CRF Receptor Binding Ligand) (US 8,551, 996 B2).

The remaining author declares that the research was conducted in the absence of any commercial or financial relationships that could be construed as a potential conflict of interest.

Copyright $\odot 2020$ Tafet and Nemeroff. This is an open-access article distributed under the terms of the Creative Commons Attribution License (CC BY). The use, distribution or reproduction in other forums is permitted, provided the original author $(s)$ and the copyright owner(s) are credited and that the original publication in this journal is cited, in accordance with accepted academic practice. No use, distribution or reproduction is permitted which does not comply with these terms. 